\title{
Genetic selection within Douglas fir (Pseudotsuga menziesii) in Europe for papermaking uses
}

\author{
Guillaume Chantre ${ }^{\mathrm{a} *}$, Philippe Rozenberg ${ }^{\mathrm{b}}$, Victoria Baonza ${ }^{\mathrm{c}}$, Nicola Macchioni ${ }^{\mathrm{d}}$, \\ Alain Le Turcq ${ }^{\mathrm{e}}$, Martine Rueff ${ }^{\mathrm{f}}$, Michel Petit-Conil ${ }^{\mathrm{g}}$ and Bernard Heois ${ }^{\mathrm{h}}$ \\ ${ }^{a}$ AFOCEL, Laboratoire Bois Process, Domaine de l'Étançon, 77370 Nangis, France \\ ${ }^{\mathrm{b}}$ INRA, Unité d'Amélioration, Génétique et Physiologie Forestières, 45166 Olivet, France \\ ${ }^{\mathrm{c}}$ INIA CIFOR, Area de Industrias Forestales, Carretera de la Coruna, km 7, 28040 Madrid, Spain \\ ${ }^{d}$ Istituto per la Ricerca sul Legno, CNR, Via Barazzuoli 23, 50136 Firenze, Italy

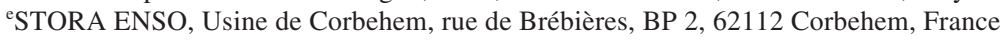 \\ ${ }^{\mathrm{f}}$ EFPG, Domaine Universitaire, 461 rue de la Papeterie, BP 65, 38402 Saint-Martin-d'Hères, France \\ ${ }^{\mathrm{g}}$ CTP, Domaine Universitaire, BP 251, 38044 Grenoble, France \\ ${ }^{\mathrm{h}}$ CEMAGREF, Domaine des Barres, 45290 Nogent sur Vernisson, France
}

(Received 1 September 2001; accepted 11 July 2002)

\begin{abstract}
The study aims to identify the feasibility and the relevance of a genetic selection for enhancing the pulping potential of the Douglas fir wood. At first, wood predictors for TMP potential are identified through the refining of thirty trees 17-year-old, using a specific procedure on a 12" Andritz refiner. The variations of TMP physical properties are linked with those of anatomical parameters, but also with within ring density related traits. The brightness of the unbleached TMP is negatively correlated with the red chromatic component of wood. Lignin, holocellulose and extractives content on one hand, Kraft fibre morphology on the other hand are considered to evaluate roughly the wood potential for the Kraft process. Then 15 clones out of 200 are non destructively selected within a 24-year-old German test to evaluate the range of the genetic variation of the papermaking potential. Chemical analyses give evidence of large variations of the chemical composition ratio between clones (holocellulose/lignin ratio). The clone discrimination of the fibre length is weak, but significant differences of fibre coarseness are observed as a consequence of the large variability of the latewood density levels. The industrial selection gain for pulping is discussed on the basis of TMP pilot plant tests which show large differences of physical and optical TMP properties between average wood assortments of each clone. This leads to practical recommendations for breeders considering the expectations of both the pulping and the wood industry.
\end{abstract}

wood quality / TMP / Kraft pulp / genetic selection / Pseudotsuga menziesii

Résumé - Sélection génétique du Douglas (Pseudotsuga menziesii) en Europe pour des usages papetiers. L'étude vise à connaître la faisabilité et la pertinence d'une sélection génétique pour améliorer le potentiel papetier du bois de Douglas. Dans un premier temps sont identifiés des indicateurs de qualité du bois pour la pâte TMP au travers du défibrage de 30 arbres âgés de 17 ans sur un pilote Andritz 12". Les variations de propriétés physiques des pâtes TMP sont liées à celles de paramètres anatomiques, mais aussi à des variations de densité intra-cerne. La blancheur des pâtes écrues est négativement corrélée à la composante chromatique rouge du bois. Les taux de lignine, holocellulose et taux d'extraits d'une part, les caractéristiques morphologiques des fibres d'autre part, sont mesurés pour évaluer sommairement le potentiel du bois dans le procédé Kraft. Dans un second temps, 15 clones sont sélectionnés parmi 200 de façon non destructive au sein d'un test clonal allemand âgé de 24 ans, afin d'évaluer l'ampleur de la variation génétique du potentiel papetier. Les analyses chimiques mettent en évidence de forts contrastes entre clones du point de vue de la composition chimique (rapport holocellulose/lignine). La différenciation des clones est faible pour la longueur des fibres, à la différence de la masse linéique des fibres, conséquence d'une forte variation de la densité du bois d'été entre clones. Dans une perspective industrielle, le gain potentiel lié à la sélection est discuté sur la base de tests menés dans un pilote TMP qui mettent à jour d'importants écarts de propriétés physiques et optiques des pâtes issues de lots moyens de bois par clone. Ceci conduit à des recommandations pratiques pour les sélectionneurs, tenant compte des attentes respectives de l'industrie des pâtes et de l'industrie du bois.

qualité du bois / TMP / pâte Kraft / sélection génétique/ Pseudotsuga menziesii

\footnotetext{
* Correspondence and reprints

Tel.: +33 (0)1 606702 49; fax: +33 (0)1 606702 56; e-mail: chantre@ afocel.fr
} 


\section{INTRODUCTION}

For thirty years, Douglas fir has been widely planted in Europe, especially in France and Germany, and nowadays this specie represents an emerging resource, for both sawing logs and thinning logs, top logs and sawmill chips. In particular, the French annual harvest of Douglas fir should be double by 2015 (around 6 million $\mathrm{m}^{3}$ ). The crisis in the Norway spruce development in many countries suggests the possibility of a partial substitution of fir and spruce by Douglas fir within Thermo-Mechanical Pulp (TMP) requiring white wood. More generally speaking, the question is posed about the relevance of the integration of pulping parameters in Douglas fir breeding programmes, without jeopardising the solid wood properties. The problem of integrating Douglas fir in substitution to Norway spruce in TMP has been demonstrated [15, 17, 20]; Douglas fir chips severely affect the optical properties (scattering, brightness and bleachability) and physical properties like breaking length and burst index. Even though some process adaptations were tried [16] as chemical pre-treatment and oxidative/reductive sequences to improve the bleachability, the possible gain linked to genetic selection is still to be evaluated.

The breeding programmes for Douglas fir are rather recent in Europe. For instance, the selection of the better adapted provenances for France (west Washington and north west Oregon) occurred between 1978 and 1981, then 1000 progenies coming from Washington and Oregon best provenances were analysed from 1989 to 1996. From 1998 until 2004, 600 clones will be selected to compose the breeding population, then the main seed orchards. The possible conflict between different goals of selection for wood quality is an important issue. It is well known that European Douglas fir presents both a high growth potential and a high wood mechanical stiffness [14], with a ratio density/ring width much higher than the other European conifers. The mechanical stiffness of the Douglas fir wood is mainly a consequence of the high density and the high proportion of the latewood. This also implies some technological drawbacks especially with machining [13] and peeling [10,11] for which tearing and lathe checks are closely linked with within-ring density variations. The genetic variability of the within ring heterogeneity of density of Douglas fir has been already studied $[9,12]$ by Keller and Nepveu who suggested selection of families within the best provenances by evaluating a high potential gain on this parameter: the within ring heterogeneity of density varies from $15 \%$ to $28 \%$ between progenies of 10 provenances. From recent experience, it is also obvious the within ring density components of conifers is highly correlated with mechanical properties of solid wood [18] as well as the fibre morphology, thus the papermaking potential $[3,5,18]$.

For these reasons, the present study - achieved within the frame of the European project EUDIREC (FAIR CT 95-0909) - deals with the practical feasibility and the relevance of genetic selection focused on the pulping potential of the Douglas fir wood, by considering (i) the range of the genetic variability within selected provenances and (ii) the relationships between the pulp and paper properties and the fitness for solid wood products.

\section{MATERIALS AND METHODS}

\subsection{Methods and sample to identify papermaking predictors in wood}

\subsubsection{Plant material}

Thirty Douglas fir thinning logs were sampled from a 26-year-old AFOCEL experimental plot, (« Le Breuil », Centre of France) with diameter at breast height being between 15 and $25 \mathrm{~cm}$. Between $1 \mathrm{~m}$ and $2 \mathrm{~m}$ above ground, sampled disks were cut for physical, chemical and anatomical analysis and 60-90 cm long logs for mechanical testing. Disks for pulping (TMP, Kraft) are sampled at $0.8 \mathrm{~m}$ and $3 \mathrm{~m}$.

\subsubsection{TRMP procedure for small scale testing}

An original procedure is elaborated on a $305 \mathrm{~mm}$ Sprout Waldron refiner, which consists in refining a small amount of wood (50 to $200 \mathrm{~g}$ air-dry wood) at $90{ }^{\circ} \mathrm{C}$ : the chips are saturated and steamed at $100{ }^{\circ} \mathrm{C}$ before refining with the temperature kept close to $100{ }^{\circ} \mathrm{C}$, then the pulp is diluted to consistency of $1.2 \%$ and beaten for several cycles. Different times of beating are considered so that three Schopper degrees can be reached. Breaking length is then adjusted to $65^{\circ} \mathrm{SR}$. Using the same trees, significant correlations can be obtained between breaking length of TRMP pulps and TMP pulps coming from a semi-industrial pilot plant. Breaking length of handsheets varied from 2000 to $3000 \mathrm{~m}$ between trees. The refining procedure was described by Foesser et al. [7], then recently improved by Fauchon et al. [6] and proved to be efficient enough for a rapid rough screening of Douglas trees according to their TMP potential. Bleachability was assessed on TRMP pulps representing two levels of sampling and 3 beating levels, using $5 \% \mathrm{H}_{2} \mathrm{O}_{2}, 3.7 \% \mathrm{NaOH}$ and $4 \% \mathrm{Na}_{2} \mathrm{SiO}_{3}$, with a retention time of 4 hours at $60{ }^{\circ} \mathrm{C}$. Before and after bleaching the properties of the handsheets are evaluated according to the T222 sp-96 standard (physical testing) and T452 om-92 (brightness).

Figure 1 and photo 1 give a general picture of the refiner and the diagram of fitting for the secondary stage.

\subsection{3. $X$ ray micro-densitometry (MDM), anatomy and ultrastructure}

Diametral X-ray microdensity profiles (MDM) were recorded on each disk according to the procedure described by Rozenberg et al. [18]. Density parameters are computed from these density profiles. The volumic mass of the X-ray samples was also measured.

Cell wall thickness and lumen diameter were measured on the same samples. The sections are $20 \mu \mathrm{m}$ thick and stained with safranine. The measurements were taken using an image analyser every third annual ring on 50 cells of earlywood and 50 of latewood.

\subsubsection{Mechanical properties}

From each disk two sections were obtained from opposite diameters, from which specimens were sawn to the dimension specified to ISO Standard 4469. The mechanical tests were carried out both on 

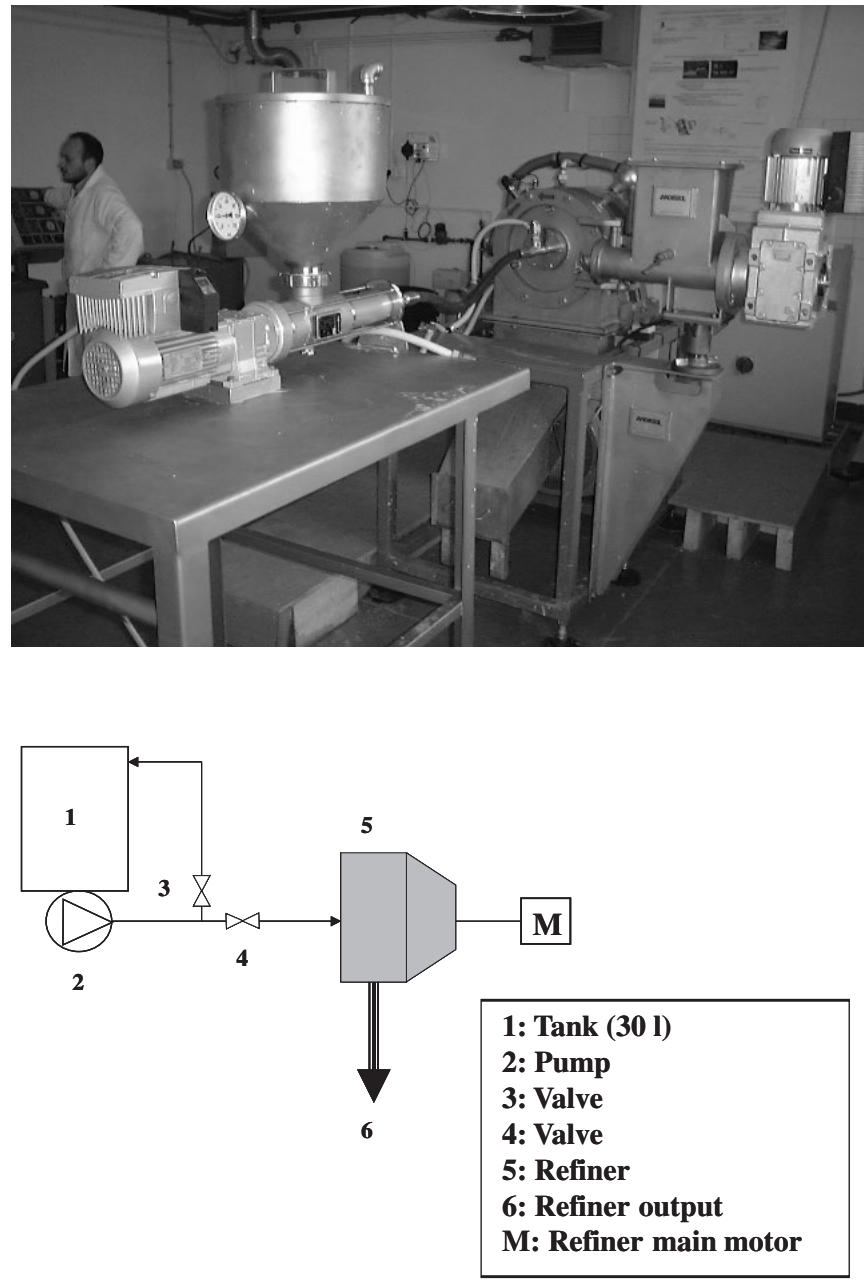

Photo 1 and Figure 1. General view of the TRMP refining pilot plant for small scale TMP potential screening, and diagram of the fitting for the secondary stage.

green material and air-dried material up to a final moisture content of about $12 \%$. Static bending Modulus of Elasticity (MOE) and Compression parallel are measured according to the standards UNE 56.537-79 and UNE 56.535-77.

\subsubsection{Wood colour and wood chemistry}

Wood colour was evaluated on the longitudinal tangential plan of polished size-calibrated TRMP chips, after stabilisation around $12 \%$ m.C., by means of a suitable spectrocolorimeter (reflectance between 400 and $700 \mathrm{~nm}$ ). Results are expressed in the CIELAB system: $L^{*}, a *, b *$. Colour was also measured on 60 mesh meal with the same apparatus.

Chemical characterization of the material was carried out by determinating the cellulose and lignin contents. Sampling was performed by cutting a slice from each stem and, after milling in a Wiley mill, collecting the 40-60 mesh wood meal through. The holocellulose and lignin contents were assessed in duplicate by the Norman and Jenkins procedure and by the method of Klason (T 222 om-88) without preliminary extraction. Extraction was done on the wood powder with water-acetone sequences using the automated extraction system SOXTEC (Foss Analytical).

\subsection{Genetic test}

\subsubsection{Plant material}

The material comes from 57 trees, 24-year-old, from 15 clones non-randomly selected in one test site (Lower Saxony, Germany). The clones in the test site were themselves selected from seedlings in Escherode (Germany), from a large seed collection in the Canada (British Columbia) and in the USA (Washington and Oregon, west of the Cascade range). The cuttings were taken from the best seedlings of the best provenances in 1975 (selection on survival and growth). The cuttings were planted in 1978 at a $2 \mathrm{~m} \times 2 \mathrm{~m}$ spacing in a trial in forest district Kattenbuehl, Lower Saxony, Germany. After the selection of the best $20 \%$ of clones in 1992, a thinning was conducted in the $80 \%$ clones not selected as superior.

The 15 clones are selected in a non destructive way using core samples in order to amplify the natural variation for density parameters and for some pulp and paper properties.

The methodology for the selection of the 15 clones is the following one: a first pre-selection was made from diameter at breast height (DBH) and Pilodyn measurements. The Pilodyn wood tester gives a rough idea of the wood density by measuring the depth of penetration of a needle propelled with an energy of $6 \mathrm{~J}$ [4]. The objective was to increase the chances of finding contrasted clones for within-ring density related traits, by concentrating the core analysis on 50 pre-selected clones out of 200 . The 50 clones were selected from around the edge of the cloud of 200 points (DBH; Pilodyn). Then, three increment cores (5 $\mathrm{mm}$ diameter) per tree were collected, and 3 to 5 trees per clone were sampled (180 trees).

Then the 15 clones were selected out of the 50 on the basis of the within ring density related traits, as described in Section 3.2.1.

The logs collected from the 15 clones were cut in the following way in order to provide the different partners with contrasted and genetically controlled wood samples:

0 to $1 \mathrm{~m}$ : wasted;

$1 \mathrm{~m}$ to $1.4 \mathrm{~m}$ : disks for extractive content, wood colour, Kraft pulping tests and fibre morphology assessment;

$1.4 \mathrm{~m}$ to $1.5 \mathrm{~m}$ : disk for X-ray micro-densitometry;

$1.5 \mathrm{~m}$ to $1.6 \mathrm{~m}$ : disk for chemical characterization;

$1.6 \mathrm{~m}$ to $2.6 \mathrm{~m}$ : $\log$ for mechanical testing;

$2.6 \mathrm{~m}$ up to the top log: $\log$ s for TMP testing.

\subsubsection{TMP procedure in the CTP pilot plant}

TMP tests were performed on an average mix of each clone (mix of 3 to 5 trees per clone). The logs were debarked, chipped, pre-heated at $110{ }^{\circ} \mathrm{C}$ during $20 \mathrm{~s}$, steamed at $115^{\circ} \mathrm{C}$ during $5 \mathrm{mn}$, then refined in two stages: first at high consistency under pressure at 3500 rpm (12" refiner - D 2 A 505 plates), secondly at medium consistency under atmospheric pressure (C2976 plates), for a target Canadian Standard Freeness $(\mathrm{CSF})=100 \mathrm{~mL}$. Then fibres were screened at low consistency with Lamort $-0.30 \mathrm{~mm}$ slots. The unbleached physical properties were determined on the 15 lots of pulp. After pre-treating with DTPA $(0.4 \%)$ the pulps were bleached using a standard bleaching $\left(5 \% \mathrm{H}_{2} \mathrm{O}_{2}\right)$. The Chemical Oxygen Demand (COD) was assessed on the effluents produced during bleaching (ISO 6060) in order to estimate the polluting charge. Physical properties were measured on the bleached pulps (T222 sp-96), including 
roughness (T452 om-96), air-permeability (T 547 pm-88), Manganese and Iron content before and after DTPA treatment.

For pratical reasons, refining curves with different CFS could not be achieved for each clone. Neverthless, it is industrially assumed that within the range $120-80 \mathrm{~mL}$ the influence of CFS on pulp strenght is negligible, so that physical properties of TMP can be used to distinguish between clones for our well defined refining conditions.

\subsubsection{Kraft pulping}

Kraft pulping tests were achieved using $150 \mathrm{~mL}$ digesters with calibrated experimental air-dry chips ( $3 \mathrm{~mm}$ thick $\times 25 \mathrm{~mm} \times 25 \mathrm{~mm}$ ). Kappa 25 was obtained on average with a white liquor active alkali $28 \%$ sulfidity $33 \%$, wood/liquor ratio $=4,90 \mathrm{mn}$ of cooking at $170{ }^{\circ} \mathrm{C}$. Pulp yield could vary from 43.5 to $47.3 \%$. Then air-dry pulps were used for fibre morphology assessment with the PQM 1000 apparatus.

\section{RESULTS}

\subsection{Identification of non destructive predictors of the papermaking potential}

A first database was built from the 30 thinning trees, in order to analyse some interactions between the wood properties and the TMP process, and to identify some non destructive predictors of the papermaking potential.

A multivariable analysis was used to identify clusters. From this, it can be observed that:

- physical properties of handsheets are linked with anatomical parameters, especially with cell wall thickness;

- initial brightness is independent of mechanical behaviour and linked with wood colour but bleachability is independent of any measured parameter;

- mechanical properties of solid wood are independent of TRMP characteristics.

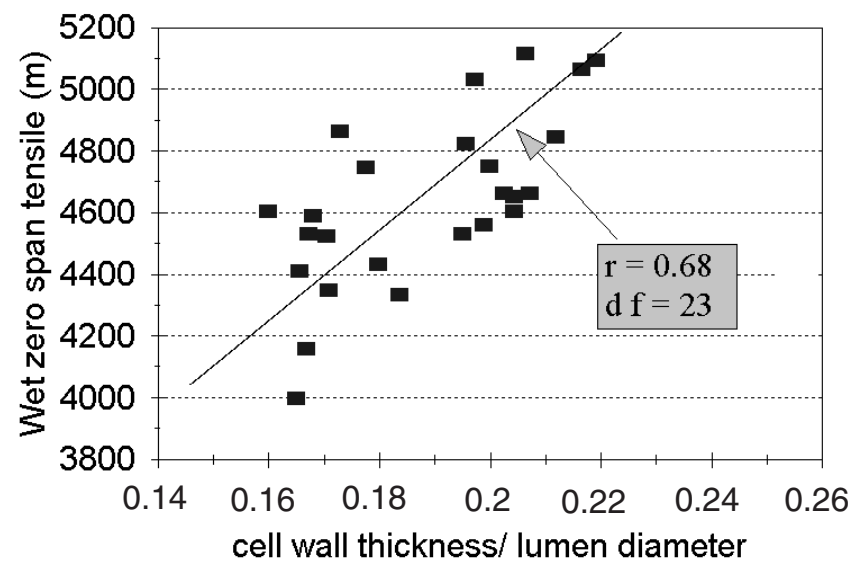

Figure 2. Relationship between the wet zero span tensile of the TRMP pulps and the ratio between cell wall thickness and lumen diameter.
The main explanatory variables for physical properties of pulps are anatomical parameters, with chemical parameters being less important. The breaking length can be predicted from a non linear model including bulk and CSF: this relationship does not depend on the height of sampling but varies between trees. For this range of consistency (less than 2\%), the TRMP pulp properties cannot be predicted with sufficient accuracy using only the fibre and wood properties. Nevertheless, the fibre strength estimated with the wet zero span tensile (standard D 5803) is significantly correlated with the ratio (cell wall thickness/lumen diameter) as shown in figure $2(\mathrm{r}=0.68, P<0.001)$. The wet zero span tensile can be considered as one of the key factors of the development of the physical properties during the TMP refining process.

Classical within ring density traits may be significantly correlated with TMP fibre traits, but alternative MDM profile analysis [18] allows better calibrations to be found between MDM parameters and complex traits like pulping ones. In particular, MDM parameters based on a moving density threshold separating the profile in 2 parts (high density profile and low density profile) can be calculated at the profile level. NB700 is the number of intersections between a density threshold at $700 \mathrm{~g} \mathrm{dm}^{-3}$ and the density profile. It is equivalent to twice the number of peaks over $700 \mathrm{~g} \mathrm{dm}^{-3}$ in the profile.

Figure 3 shows the evolution, with the threshold value, of the correlation between wet zero span tensile and NB. The

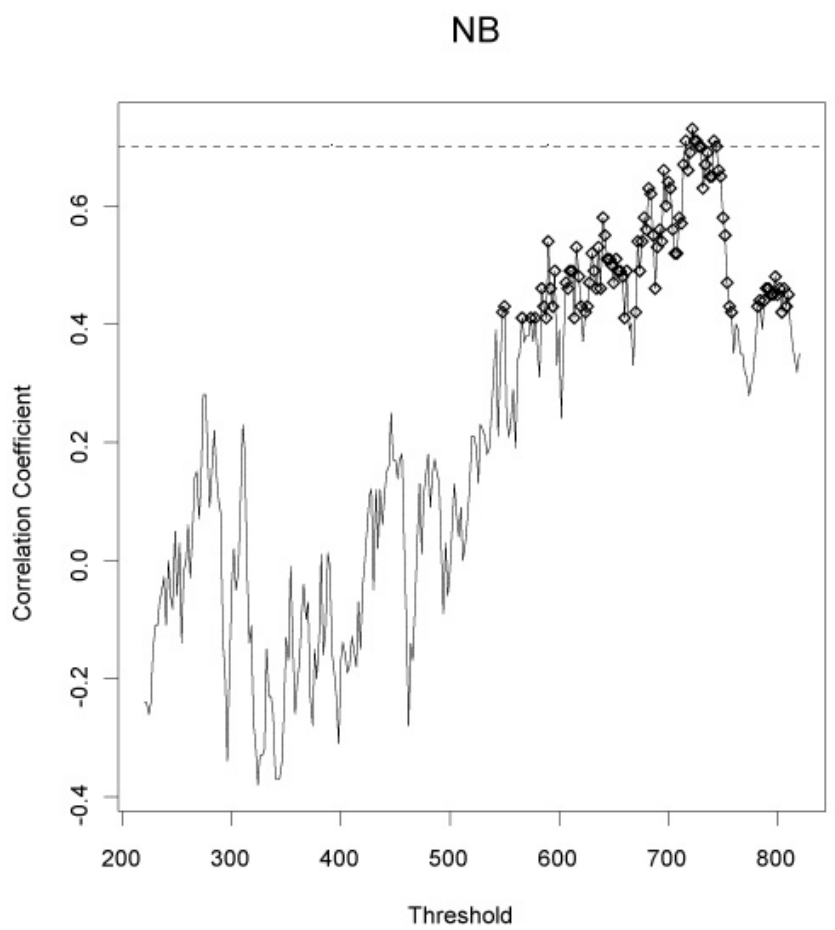

Figure 3: Evolution of the correlation between the MDM parameter NB700 and wet zero span tensile index with the threshold value. The points indicate the correlation coefficient values that are significantly different from 0 at $P=0.05 \%$. The horizontal line is for 0.7 . 
highest correlation coefficient is found for NB just above $700 \mathrm{~g} \mathrm{dm}^{-3}$, and equals $0.74(P<0.01)$. This NB 700 parameter can be considered as a rapid index of selection for the TMP fibre strength in Douglas fir. The relevance of the NB700 parameter is corroborated by the TMP analysis of the 15 clones, especially when it is combined with the average wood density (see Section 4.1).

Douglas fir Kraft fibre morphology can be also estimated directly from the MDM profile, as described by Rozenberg et al. [18], with respectively the following coefficients of correlation for average fibre width, fibre coarseness and curl index: $+0.88,+0.92,+0.82$.

Unbleached TRMP brightness can be roughly predicted from the determination of the $\mathrm{a}^{*}$ chromatic component variations in wood (red colour), with the correlation being high enough for screening trees $(\mathrm{r}=0.7, P<0.001)$. The result is illustrated in figure 4 . The $\mathrm{b}^{*}$ chromatic component of pulp is correlated with latewood content and not with $b^{*}$ of wood.

After bleaching, the achieved level of brightness was around 76, which is good for printing. But the high level of Iron detected in pulp with low bleachability (more than $300 \mathrm{ppm}$ ) indicates plate wear in the refiner, and prevents identification of the relevant wood chemical predictor. For this reason, increment cores were ground in a Wiley mill, then sieved and bleached according to the conventional bleaching sequence applied to the pulp. Reflectance was measured before and after bleaching at $450 \mathrm{~nm}$ (RI 450 and RF 450) to estimate bleachability.

\subsection{Genetic variability (clonal test)}

\subsubsection{Methodology for the selection of 15 clones with contrasted pulping traits}

In order to select the most variable clones for both solid wood and pulping traits, clones were selected to represent a

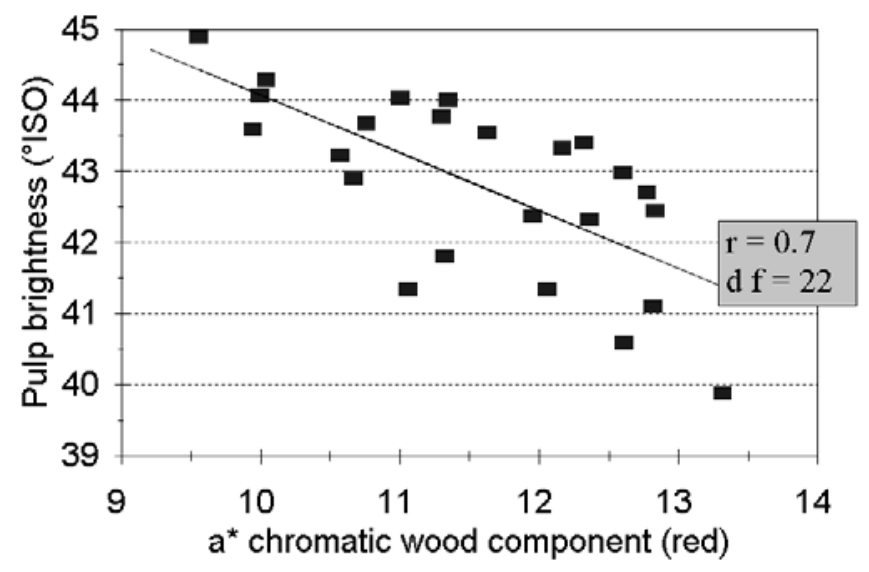

Figure 4. Relationship between the unbleached TRMP brightness and the wood colour ( $\mathrm{a}^{*}$ chromatic component in the longitudinal tangential wood section). wide range of NB 700, RI450 and RF 450 variations. Approximately 180 trees were analysed, with the following constraints: (1) within-clone variation has to be limited; (2) wood density, within-ring heterogeneity of density, late wood percentage have to be contrasted.

Figures 5 and 6 show the distribution of the selected clones (each point being the average of the 3 to 5 trees per clone) compared to the others, for some of the pre-cited parameters of selection.

\subsubsection{Clonal variability of within-ring density related traits}

The NB700 trait was computed from the density profiles recorded on the increment cores collected on these clones. As

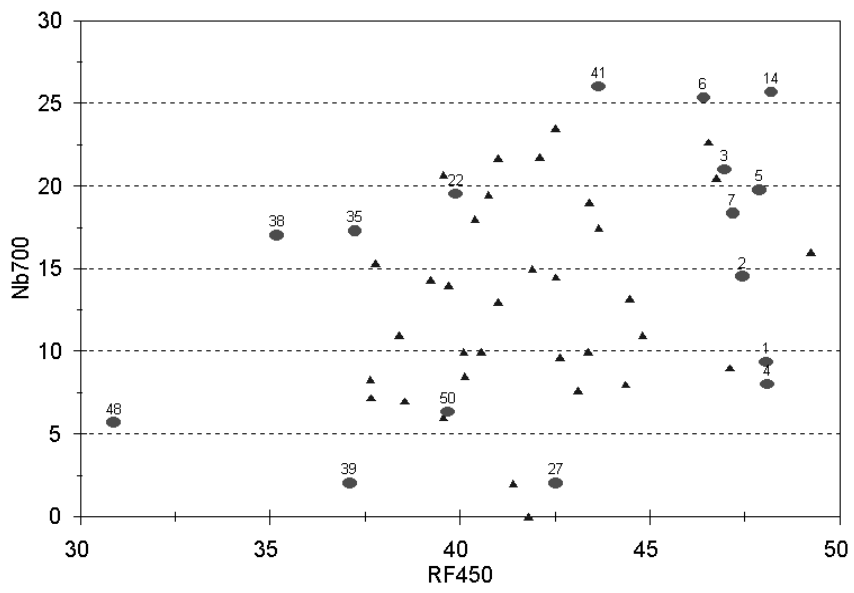

Figure 5. Position of the selected clones among the others for the following parameters: NB 700 and wood reflectance after bleaching (RF 450).

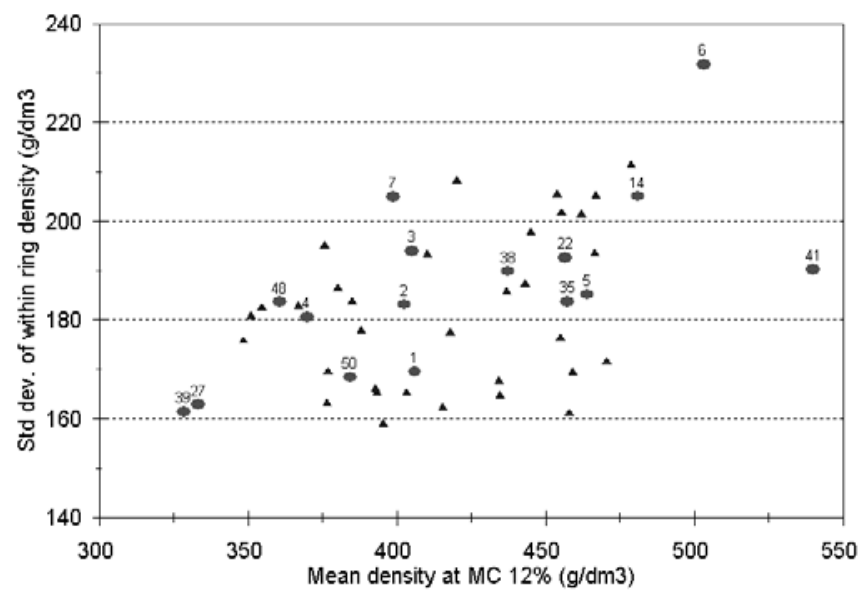

Figure 6. Position of the selected clones among the others for the following parameters: within-ring heterogeneity of density (std dev) and mean wood density at M.C. $12 \%$. 
Table I. Analysis of variance of the NB 700 parameter.

\begin{tabular}{lccccc}
\hline Source & Sum of Squares & DF & Mean Square & F & P $(\%)$ \\
\hline Model (clone) & 6711 & 49 & 136.96 & 3.8 & 0.00 \\
Error & 4130 & 116 & 35.60 & & \\
Total & 10840 & 165 & 65.70 & & \\
\hline
\end{tabular}

shown in table I (analysis of variance of NB 700) and table II (clone effect of the different MDM traits), while $\mathrm{F}$ value for NB 700 is similar to that found for the classical within density parameters, the clonal coefficient of variation of this trait is much higher than the clonal coefficient of variation of the ring density parameters: $58 \%$, while the highest is $34 \%$ for earlywood width. Higher genetic variation might be expected for NB700 than for other wood quality traits.

Wood density is under strict genetic control, as already mentioned by several authors $[1,19,21]$. In our test, the variation of density between extreme clones is huge: from 320 to $550 \mathrm{~kg} \mathrm{~m}^{-3}$, with correlatively drastic effects on all mechanical properties (see Section 4.1) with MOE varying from 7480 to $12500 \mathrm{MPa}$. It is obviously necessary to take into account the average density in the selection objectives to meet the minimum structural lumber requirements.

\subsubsection{Pulping and chemical traits}

The TMP results are reported in table III. The range of variation is industrially significant for any parameter.

An important scattering can be observed. For some clones, it is possible to achieve the CSF target with a low energy, when others are less suitable for TMP due to the high level of energy, but generally speaking the energy consumption is not a limiting factor for Douglas fir.

Four clones give a final brightness higher than 78 after bleaching, which is convenient with the Corbehem's mill targets. Alkaline and standard bleaching results are the same. Chelating treatment is not necessary because of a very low Manganese content. Three clones give very favourable levels of resistance: 3099-751, 2464-751 and 5286-751. The clone 5286-751 gives mechanical properties close to the pulp mill reference as presented in table $I V$ (this mix of Norway spruce and poplar, tested on the same pilot plant, can be considered as the target of supply quality for the Corbehem's pulp and paper mill). But permeability and roughness are always much higher for the Douglas fir TMP than for the mill reference.
The bleaching sequences drastically decrease the level of these properties, but not enough to meet the requirements of a standard Light Weight Coated utilization $(\mathrm{LWC}=$ magazine paper).

The main problem remains the prohibitive level of Chemical Oxygen Demand (COD) of the effluents produced during bleaching of Douglas fir TMP, since it is 3 to 4 times higher than the mill's standard bleaching reference.

Data of lignin content on oven dry unextracted 40-60 mesh meals showed a range between $28.2 \%$ and $32.5 \%$ a mean of $30.0 \%$. The clone effect is highly significant $(P<0.001)$ as it can be observed in figure 7 . Holocellulose determinations are included between $57.6 \%$ and $63.0 \%$ and show a mean of $60.8 \%$. However, they give also evidence the higher the holocellulose content, the lower the lignin content (see table $V$ ) and the possibility to select clones with significantly higher chemical pulping yield than the average Douglas fir resource.

The within clone variance was much higher for extractives content than for the lignin and cellulose content. The fibre morphology is partially under genetic control. The clonal discrimination of the fibre length was weak, but the clonal effect on the fibre coarseness was high, as a consequence of the huge clonal variability of the latewood density levels, with a $28 \%$ difference between the extreme clones. High differences of Kraft pulp properties can be expected from these variations, especially for tear and burst index [5].

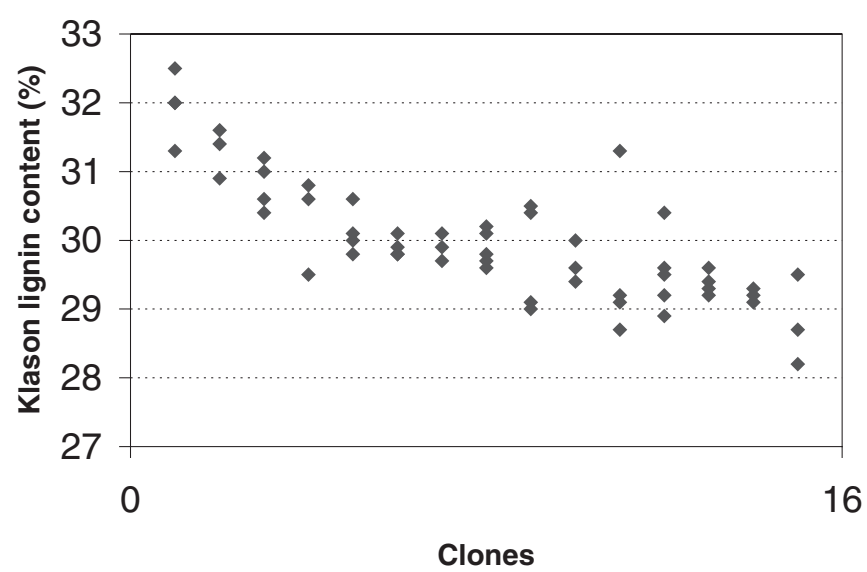

Figure 7. Variation of Klason lignin content between the 15 Douglas fir clones.

Table II. Clone effect (F statistic) and variation (clonal coefficient of variation) for within-ring density parameters and NB 700.

\begin{tabular}{lcccccccccc}
\hline & $\begin{array}{c}\text { Ring } \\
\text { width } \\
(\mathrm{mm})\end{array}$ & $\begin{array}{c}\text { Earlywood } \\
\text { width } \\
(\mathrm{mm})\end{array}$ & $\begin{array}{c}\text { Latewood } \\
\text { width } \\
(\mathrm{mm})\end{array}$ & $\begin{array}{c}\text { Ring } \\
\text { density } \\
\left(\mathrm{kg} \mathrm{m}^{-3}\right)\end{array}$ & $\begin{array}{c}\text { Earlywood } \\
\text { density } \\
\left(\mathrm{kg} \mathrm{m}^{-3}\right)\end{array}$ & $\begin{array}{c}\text { Latewood } \\
\text { density } \\
\left(\mathrm{kg} \mathrm{m}^{-3}\right)\end{array}$ & $\begin{array}{c}\text { Minimum } \\
\text { density } \\
\left(\mathrm{kg} \mathrm{m}^{-3}\right)\end{array}$ & $\begin{array}{c}\text { Maximum } \\
\text { density } \\
\left(\mathrm{kg} \mathrm{m}^{-3}\right)\end{array}$ & $\begin{array}{c}\text { Ring standard } \\
\text { deviation } \\
\left(\mathrm{kg} \mathrm{m}^{-3}\right)\end{array}$ & $\begin{array}{c}\text { NB } \\
700\end{array}$ \\
\hline Clone effect (F) & 5.6 & 6.2 & 4.5 & 7.1 & 2.9 & 4.0 & 2.7 & 3.8 & 3.5 & 3.8 \\
Variation $(\mathrm{CV})$ & 0.28 & 0.34 & 0.30 & 0.13 & 0.14 & 0.09 & 0.18 & 0.09 & 0.12 & 0.58 \\
\hline
\end{tabular}


Table III. Average TMP properties for the 15 selected clones (results obtained from the CTP TMP pilot plant).

\begin{tabular}{|c|c|c|c|c|c|c|c|c|c|c|c|c|c|c|c|}
\hline Clones & $\begin{array}{c}3099- \\
751\end{array}$ & $\begin{array}{c}5451- \\
751\end{array}$ & $\begin{array}{c}1626- \\
751\end{array}$ & $\begin{array}{c}2464- \\
751\end{array}$ & $\begin{array}{c}2993- \\
751\end{array}$ & $\begin{array}{c}3029- \\
751\end{array}$ & $\begin{array}{c}3307- \\
751\end{array}$ & $\begin{array}{c}5286- \\
751\end{array}$ & $\begin{array}{c}6652- \\
751\end{array}$ & $\begin{array}{c}5230- \\
751\end{array}$ & $\begin{array}{c}3223- \\
751\end{array}$ & $\begin{array}{c}3056- \\
751\end{array}$ & $\begin{array}{c}3031- \\
751\end{array}$ & $\begin{array}{c}3097- \\
751\end{array}$ & $\begin{array}{c}3157- \\
751\end{array}$ \\
\hline $\begin{array}{l}\text { Total energy } \\
\text { Consumption } \\
\left(\mathrm{kWh} \mathrm{t}^{-1}\right)\end{array}$ & 2308 & 2313 & 2379 & 2018 & 2292 & 2026 & 2141 & 2355 & 2172 & 2309 & 2377 & 2019 & 2258 & 2440 & 2406 \\
\hline \multicolumn{16}{|l|}{ Unbleached pulp } \\
\hline CSF & 98 & 98 & 120 & 105 & 115 & 131 & 105 & 105 & 110 & 110 & 114 & 102 & 100 & 90 & 109 \\
\hline $\begin{array}{l}\text { Breaking } \\
\text { length (m) }\end{array}$ & 3615 & 2409 & 2249 & 3352 & 2752 & 2065 & 2723 & 3357 & 2688 & 2938 & 2941 & 2912 & 2658 & 3012 & 2990 \\
\hline Stretch $(\%)$ & 1.61 & 1.53 & 1.60 & 1.57 & 1.42 & 1.32 & 1.46 & 1.73 & 1.72 & 1.42 & 1.75 & 1.55 & 1.66 & 1.68 & 1.68 \\
\hline $\begin{array}{l}\text { Burst index } \\
\left(\mathrm{kPa} \mathrm{m}^{2} \mathrm{~g}^{-1}\right)\end{array}$ & 14.8 & 8.9 & 9.2 & 13.5 & 10.4 & 7.6 & 10.7 & 15.2 & 11.8 & 12.0 & 12.3 & 12.3 & 10.9 & 11.5 & 12.7 \\
\hline $\begin{array}{l}\text { Tear index } \\
\left(\mathrm{mN} \mathrm{m}^{2} \mathrm{~g}^{-1}\right)\end{array}$ & 41.0 & 32.2 & 34.2 & 40.6 & 36.7 & 26.3 & 35.0 & 49.8 & 42.0 & 38.2 & 44.4 & 38.8 & 33.8 & 36.6 & 36.2 \\
\hline $\begin{array}{l}\text { Brightness } \\
(\%)\end{array}$ & 48.8 & 47.1 & 49.4 & 47.4 & 52.3 & 51.1 & 49.5 & 49.3 & 48.5 & 52.3 & 51.0 & 53.2 & 46.1 & 50.1 & 47.2 \\
\hline $\begin{array}{l}\text { Air permeability } \\
\left(\mathrm{mL} \mathrm{mn}^{-1}\right)\end{array}$ & 229 & 615 & 664 & 327 & 752 & 1100 & 638 & 478 & 432 & 383 & 518 & 368 & 578 & 318 & 376 \\
\hline $\begin{array}{l}\text { Roughness } \\
\left(\mathrm{mL} \mathrm{mn}^{-1}\right)\end{array}$ & 406 & 681 & 787 & 435 & 578 & 791 & 592 & 554 & 558 & 502 & 763 & 427 & 580 & 355 & 422 \\
\hline $\begin{array}{l}\text { TMP Fibre } \\
\text { Length }(\mathrm{mm})\end{array}$ & 0.91 & 0.77 & 0.80 & 0.84 & 0.85 & 0.76 & 0.83 & 1.01 & 0.93 & 0.83 & 0.93 & 0.80 & 0.83 & 0.80 & 0.82 \\
\hline \multicolumn{16}{|l|}{ Bleached pulp } \\
\hline CSF & 98 & 106 & 122 & 131 & 122 & 130 & 133 & 133 & 122 & 100 & 144 & 125 & 120 & 90 & 100 \\
\hline $\begin{array}{l}\text { Breaking } \\
\text { length (m) }\end{array}$ & 3123 & 2581 & 2320 & 2947 & 2691 & 2250 & 2645 & 3124 & 2766 & 2565 & 2530 & 2731 & 2520 & 2886 & 3151 \\
\hline Stretch $(\%)$ & 1.55 & 1.15 & 1.24 & 1.47 & 1.41 & 1.21 & 1.50 & 1.90 & 1.59 & 1.46 & 1.51 & 1.35 & 1.35 & 1.44 & 1.36 \\
\hline $\begin{array}{l}\text { Burst index } \\
\left(\mathrm{kPa} \mathrm{m}^{2} \mathrm{~g}^{-1}\right)\end{array}$ & 11.2 & 8.8 & 8.8 & 11.1 & 9.6 & 7.7 & 10.0 & 12.9 & 11.0 & 9.6 & 9.4 & 11.2 & 10.0 & 11.5 & 11.5 \\
\hline $\begin{array}{l}\text { Tear index } \\
\left(\mathrm{mN} \mathrm{m}^{2} \mathrm{~g}^{-1}\right)\end{array}$ & 38.3 & 36.5 & 34.1 & 38.9 & 41.4 & 27.4 & 37.3 & 52.8 & 44.0 & 39.1 & 43.2 & 33.2 & 35.7 & 36.8 & 34.2 \\
\hline $\begin{array}{l}\text { Brightness } \\
\text { ('ISO) }\end{array}$ & 75.8 & 74.5 & 75.0 & 73.6 & 76.9 & 77.4 & 79.1 & 78.1 & 78.5 & 76.4 & 75.8 & 75.7 & 72.2 & 79.0 & 75.4 \\
\hline $\begin{array}{l}\text { Air permeability } \\
\left(\mathrm{mL} \mathrm{mn}^{-1}\right)\end{array}$ & 185 & 467 & 465 & 261 & 471 & 531 & 382 & 334 & 340 & 319 & 375 & 182 & 390 & 173 & 137 \\
\hline $\begin{array}{c}\text { Roughness } \\
\left(\mathrm{mL} \mathrm{mn}^{-1}\right)\end{array}$ & 312 & 516 & 406 & 230 & 367 & 413 & 332 & 297 & 317 & 293 & 344 & 171 & 300 & 186 & 165 \\
\hline $\begin{array}{l}\text { TMP Fibre } \\
\text { Length (mm) }\end{array}$ & 0.77 & 1.01 & 0.94 & 0.80 & 0.82 & 0.73 & 0.76 & 0.95 & 0.86 & 0.77 & 0.86 & 0.73 & 0.79 & 0.72 & 0.74 \\
\hline $\operatorname{COD}\left(\mathrm{kg} \mathrm{t}^{-1}\right)$ & 235 & 257 & 251 & 363 & 326 & 324 & 253 & 274 & 271 & 318 & 277 & 294 & 333 & 326 & 327 \\
\hline $\begin{array}{l}\text { Brightness } \\
\text { variation }\end{array}$ & 27.0 & 27.4 & 25.6 & 26.2 & 24.6 & 26.3 & 29.6 & 28.8 & 30.0 & 24.1 & 24.8 & 22.5 & 26.1 & 28.9 & 28.2 \\
\hline
\end{tabular}

\section{DISCUSSION}

\subsection{Correlation between traits}

Even if the results presented are based on a too limited sample from Douglas fir breeding populations to be generalised and thus should be considered cautiously, the analysis of the variability of the TMP characteristics of the clones allows significant correlations to be identified with some of them being relevant for tree breeders.
Within table $V$, correlations are presented between some clonal means of bleached pulp traits and wood traits. The determination of the latewood density is accurate enough to select clones on their average fibre coarseness $(r=+0.86)$ or even better, the ratio between fibre coarseness and width ${ }^{2}$ $(\mathrm{r}=+0.9)$; the other way round the determination of the ratio "coarseness/width" 2 " can be an accurate index for discriminating the mechanical wood stiffness of clones $(r=+0.93)$.

Knowing the handsheet formation is mainly determined by the fibre flexibility, the high levels of bulk density, roughness 
Table IV. Comparison between the TMP potential of the clone 5286-751 and the standard reference of the STORAENSO Corbehem mix $(75 \%$ Norway spruce and $25 \%$ Poplar). Results obtained on the CTP TMP pilot plant.

\begin{tabular}{|c|c|c|}
\hline & Clone 5286-751 & STORAENSO Corbehem reference \\
\hline Douglas (\%) & 100 & 0 \\
\hline Poplar (\%) & 0 & 25 \\
\hline Spruce $(\%)$ & 0 & 75 \\
\hline $\mathrm{CSF}(\mathrm{ml})$ & 105 & 90 \\
\hline Energy $\left(\mathrm{kWh} \mathrm{t}^{-1}\right)$ & 2355 & 2740 \\
\hline Breaking Length (m) & 3357 & 3230 \\
\hline Stretch $(\%)$ & 1.73 & 1.62 \\
\hline Burst index $\left(\mathrm{kPa} \mathrm{m}^{2} \mathrm{~g}^{-1}\right)$ & 15.2 & 15.1 \\
\hline Tear index $\left(\mathrm{mN} \mathrm{m}^{2} \mathrm{~g}^{-1}\right)$ & 49.8 & 44.6 \\
\hline Brightness (\%) & 49.3 & 58.6 \\
\hline Porosity $\left(\mathrm{mL} \mathrm{mn}^{-1}\right)$ & 478 & 266 \\
\hline Roughness $\left(\mathrm{mL} \mathrm{mn}{ }^{-1}\right)$ & 554 & 317 \\
\hline Average length (mm) & 1.01 & 0.93 \\
\hline
\end{tabular}

(75\% higher than the pulp mill reference) and porosity ( $80 \%$ higher than the pulp mill reference) for the Douglas fir samples are clearly linked with the proportion of the coarse latewood fibres. Thus, the standard deviation of the wood density or the index "NB 700" (in relation with the profile heterogeneity and also the rigidity of the fibres) are important explanatory variables of the roughness, the bulk and the air-permeability. The combination of the parameter "NB 700" and the average wood density accounts for 50 to $70 \%$ of the clonal variability of bulk, permeability, roughness and breaking length. The other way round, the variation of the earlywood density does not affect the TMP physical properties.

It is thus logical to observe highly significant positive correlation between the wood stiffness (MOE) and NB 700 $(r=+0.87)$. Schematically, the coarser the fibres, (i) the less flexible fibres and the more opened structure of the handsheets, leading to poor tensile and high roughness, but (ii) the higher the solid wood strength.

Increasing the holocellulose content or decreasing the lignin content does not affect the mechanical properties.

The optical properties are linked to both the wood colour and the chemical and anatomical composition. The wood brightness ( $\mathrm{L}^{*}$ in the CIELAB system) measured on increment cores explains $44 \%$ of the variability of the yellow index of the unbleached TMP handsheets, and the yellow index difference after bleaching. The opacity, the coefficients of absorption and diffusion seem to be more linked with anatomical and chemical properties. The bleachability of the pulp can be moderately correlated with the red chromatic component $\mathrm{a}^{*}$ of the wood samples before extraction $(\mathrm{r}=-0.6$, $P=0.02)$. Of course, this complex trait should be better predicted by a specific chemical analysis.

Very high level of correlation can be observed between the MDM traits and the mechanical properties of the solid wood samples (MOE, compression) with coefficients of correlation all superior than 0.85 . The high density Douglas fir latewood mainly determines the wood stiffness.

The growth of the Douglas fir clones is independent from the wood, fibre and pulp traits (the average ring width is not significantly correlated with wood density, MDM traits, fibre morphology, TMP strength, MOE of solid wood), when, on the contrary, trade off would be required to improve volume, tear strength and tensile strength of the western hemlock TMP [8].

Non destructive selection is thus feasible, both for wood and pulp industry, with an interesting range of genetic variability. Genetic parameters are still to be evaluated.

\subsection{Towards suggestions for breeders}

The recommendations for Douglas fir wood selection could be summed up as follows:

(1) Increasing the homogeneity of the Douglas fir wood, with emphasis on simple predictors derived from the X-ray profile like NB 700, would have positive effects on the industrial products: improving the machinability of the sawn boards [13], and improving the peeling ability [10], increasing the within tree homogeneity of the wood products for dimensional stability (shrinkages of boards, plywood thickness) and for strength, increasing tensile energy of the TMP products and the burst index of the Kraft pulps [5], decreasing the roughness of the pulp and paper products which can be a bar to entering some markets as LWC. The genetic selection can be efficient from 10-year-old for the wood homogeneity [9], and the genetic correlation with growth related traits is favourable [21]. The genetic variability of heterogeneity estimators like NB 700 is high $(\mathrm{CV}>10 \%)$.

(2) Simultaneously increasing the average wood density and/or the square density profile [18], with trade-off regarding the within ring density heterogeneity, because of unfavourable genetic correlations [21]. For Douglas fir wood, wood density is a simple relevant wood property, able to predict wood stiffness and compression of sawn boards and ply-woods. Wood density combined with NB 700 can give relevant information on the physical properties of TMP. The genetic variability of the wood basic density is high $(\mathrm{CV}>10 \%)$.

(3) For the TMP process, decreasing the $a^{*}$ chromatic component would contribute increasing the brightness of Douglas fir wood. Even if the bleachability of Douglas fir TMP is high, the final brightness of pulp depends on the initial brightness of the heartwood. Decreasing the contrast between sapwood and heartwood on sawn boards can have a positive impact from an aesthetic point of view. This trait, independent from the previous ones, may be considered as a secondary target. 
Table V. Matrix of correlations between clonal means for bleached TMP, wood and fibre traits.

The first number is the coefficient of correlation $r$, the second one (in italics) is the statistical risk. List of variables:

B_BL: Breaking length of the bleached pulp

B_RE: Energy of rupture of the bleached pulp

B_ST: Stretch of the bleached pulp

B_BUR: burst index of the bleached pulp

B_TE: tear index of the bleached pulp

B_BUL: bulk density of the bleached pulp

B_WI: white index of the bleached pulp

B_OP: opacity of the bleached pulp

B_S: coefficient of scattering of the bleached pulp

B_K: coefficient of absorption of the bleached pulp

B_PE: air permeability of the bleached pulp

\author{
B_RU: rugosity of the bleached pulp \\ COD: chemical oxygen demand \\ D m: mean density at $12 \%$ m.C. \\ DINI: density of the earlywood \\ DFIN: density of the latewood \\ NB $700=$ NB 700 (MDM parameter) \\ $\mathrm{C} / \mathrm{W}^{2}=$ fibre coarseness $/$ width $^{2}$ \\ $\mathrm{K}$ Li: Klason lignin content \\ CEL: Holocellulose content \\ COMP: compression parallel of solid wood \\ MOE: Modulus of Elasticity
}

B_BL B_RE B_ST B_BUR B_TE B_BULB_WI B_OP B_S B_K B_PE B_RU COD DM DINI DFIN NB700 C/W ${ }^{2}$ K Li CEL COMP MOE

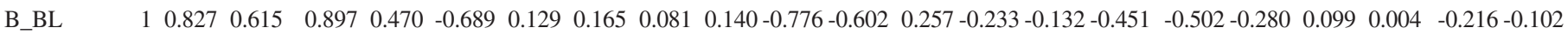
$\begin{array}{lllllllllllllllllllllll}0 & 0.000 & 0.015 & 0.000 & 0.077 & 0.005 & 0.646 & 0.556 & 0.773 & 0.618 & 0.001 & 0.018 & 0.355 & 0.404 & 0.640 & 0.091 & 0.057 & 0.312 & 0.725 & 0.990 & 0.440 & 0.718\end{array}$

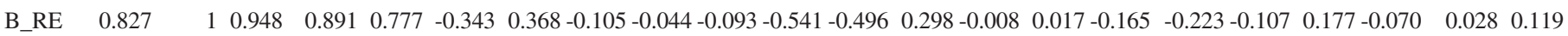
$\begin{array}{lllllllllllllllllllllll}0.000 & 0 & 0.000 & 0.000 & 0.001 & 0.211 & 0.177 & 0.711 & 0.875 & 0.742 & 0.037 & 0.060 & 0.280 & 0.977 & 0.951 & 0.557 & 0.424 & 0.703 & 0.528 & 0.804 & 0.923 & 0.673\end{array}$

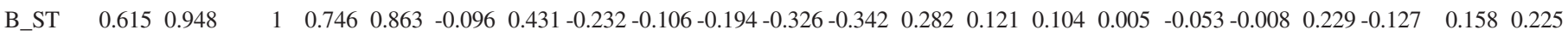
$\begin{array}{lllllllllllllllllllllll}0.015 & 0.000 & 0 & 0.001 & 0.000 & 0.733 & 0.109 & 0.406 & 0.708 & 0.489 & 0.236 & 0.213 & 0.309 & 0.667 & 0.711 & 0.985 & 0.852 & 0.976 & 0.412 & 0.651 & 0.575 & 0.419\end{array}$

$\begin{array}{lllllllllllllllllllllllllll}\text { B_BUR } & 0.897 & 0.891 & 0.746 & 1 & 0.574 & -0.615 & 0.199 & 0.134 & 0.106 & 0.071 & -0.769 & -0.723 & 0.316 & -0.203 & -0.145 & -0.397 & -0.460 & -0.298 & 0.271 & -0.215 & -0.181 & -0.097\end{array}$ $\begin{array}{llllllllllllllllllllll}0.000 & 0.000 & 0.001 & 0 & 0.025 & 0.015 & 0.477 & 0.633 & 0.706 & 0.803 & 0.001 & 0.002 & 0.251 & 0.467 & 0.605 & 0.143 & 0.085 & 0.280 & 0.329 & 0.442 & 0.518 & 0.731\end{array}$

$\begin{array}{lllllllllllllllllllllll}\text { B_TE } & 0.470 & 0.777 & 0.863 & 0.574 & 1 & 0.138 & 0.271 & -0.371 & -0.309 & -0.171 & -0.070 & -0.035 & 0.072 & 0.193 & 0.265 & 0.079 & 0.043 & 0.002 & 0.237 & -0.123 & 0.234 & 0.252\end{array}$ $\begin{array}{llllllllllllllllllllll}0.077 & 0.001 & 0.000 & 0.025 & 0 & 0.624 & 0.329 & 0.174 & 0.262 & 0.543 & 0.805 & 0.900 & 0.799 & 0.492 & 0.340 & 0.781 & 0.879 & 0.993 & 0.394 & 0.663 & 0.401 & 0.366\end{array}$

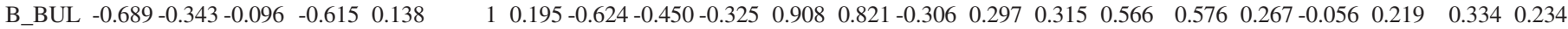
$\begin{array}{llllllllllllllllllllllllll}0.005 & 0.211 & 0.733 & 0.015 & 0.624 & 0 & 0.486 & 0.013 & 0.092 & 0.238 & 0.000 & 0.000 & 0.267 & 0.282 & 0.252 & 0.028 & 0.025 & 0.336 & 0.842 & 0.432 & 0.224 & 0.402\end{array}$

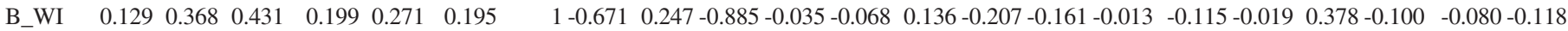
$\begin{array}{llllllllllllllllllllll}0.646 & 0.177 & 0.109 & 0.477 & 0.329 & 0.486 & 0 & 0.006 & 0.374 & 0.000 & 0.903 & 0.811 & 0.629 & 0.460 & 0.566 & 0.963 & 0.682 & 0.945 & 0.165 & 0.722 & 0.777 & 0.675\end{array}$

B_OP $\quad 0.165-0.105-0.232 \quad 0.134-0.371 \quad-0.624-0.671 \quad 1 \quad 0.378 \quad 0.750-0.473-0.537 \quad 0.243-0.028-0.114-0.368 \quad-0.267-0.172-0.010-0.227 \quad-0.192-0.133$

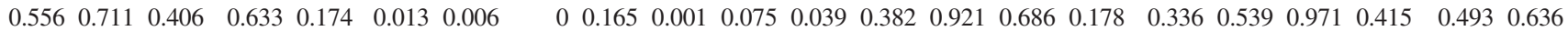

B_S $\quad 0.081-0.044-0.106 \quad 0.106-0.309-0.450 \quad 0.247 \quad 0.378 \quad 1-0.288-0.531-0.564 \quad 0.048-0.462-0.494-0.615 \quad-0.573-0.401 \quad 0.511-0.614 \quad-0.536-0.595$ $\begin{array}{llllllllllllllllllllllllll}0.773 & 0.875 & 0.708 & 0.706 & 0.262 & 0.092 & 0.374 & 0.165 & 0 & 0.297 & 0.042 & 0.029 & 0.865 & 0.083 & 0.061 & 0.015 & 0.026 & 0.138 & 0.052 & 0.015 & 0.039 & 0.019\end{array}$

B_K $\quad 0.140-0.093-0.194 \quad 0.071-0.171 \quad-0.325-0.885 \quad 0.750-0.288$

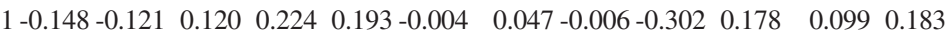
$\begin{array}{llllllllll}0.618 & 0.742 & 0.489 & 0.803 & 0.543 & 0.238 & 0.000 & 0.001 & 0.297\end{array}$

$\begin{array}{lllllllllllll}0 & 0.598 & 0.668 & 0.671 & 0.423 & 0.490 & 0.988 & 0.869 & 0.982 & 0.274 & 0.525 & 0.726 & 0.513\end{array}$

B_PE $\quad-0.776-0.541-0.326-0.769-0.070 \quad 0.908-0.035-0.473-0.531-0.148$

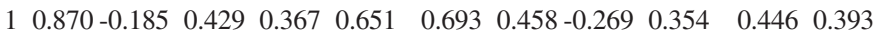
$\begin{array}{llllllllllll}0.001 & 0.037 & 0.236 & 0.001 & 0.805 & 0.000 & 0.903 & 0.075 & 0.042 & 0.598\end{array}$

$\begin{array}{llllllllllll}0 & 0.000 & 0.509 & 0.111 & 0.178 & 0.009 & 0.004 & 0.086 & 0.333 & 0.195 & 0.095 & 0.147\end{array}$ 
Table V. Continued.

B_BL B_RE B_ST B_BUR B_TE B_BULB_WI B_OP B_S B_K B_POB_RU COD D M D INI DFIN NB700 C/W ${ }^{2}$ K Li CEL COMP MOE

B_RU $\quad-0.602-0.496-0.342 \quad-0.723-0.035 \quad 0.821-0.068-0.537-0.564-0.121 \quad 0.870$

$\begin{array}{lllllllll}1-0.507 & 0.302 & 0.371 & 0.538 & 0.541 & 0.344-0.404 & 0.490 & 0.365 & 0.306\end{array}$

$\begin{array}{lllllllllll}0.018 & 0.060 & 0.213 & 0.002 & 0.900 & 0.000 & 0.811 & 0.039 & 0.029 & 0.668 & 0.000\end{array}$

$\begin{array}{lllllllllllll}0 & 0.054 & 0.274 & 0.173 & 0.039 & 0.037 & 0.209 & 0.135 & 0.064 & 0.181 & 0.267\end{array}$

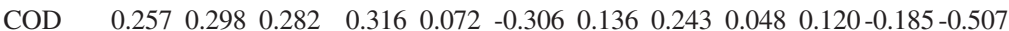

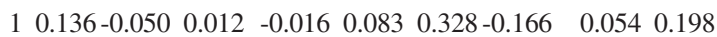
$\begin{array}{llllllllllll}0.355 & 0.280 & 0.309 & 0.251 & 0.799 & 0.267 & 0.629 & 0.382 & 0.865 & 0.671 & 0.509 & 0.054\end{array}$

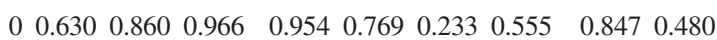

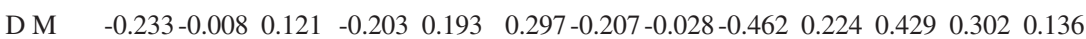

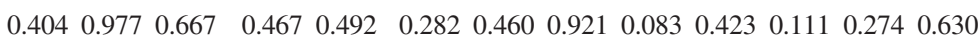

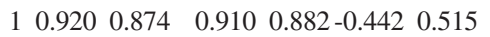

0.9680 .944 $\begin{array}{lllllllll}0 & 0.000 & 0.000 & 0.000 & 0.000 & 0.086 & 0.041 & 0.000 & 0.000\end{array}$

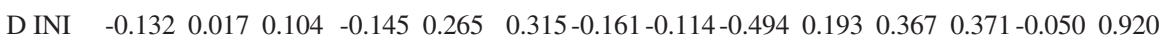

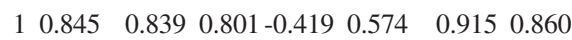

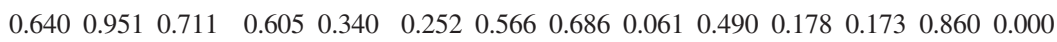

$\begin{array}{llllllll}0 & 0.000 & 0.000 & 0.000 & 0.106 & 0.020 & 0.000 & 0.000\end{array}$

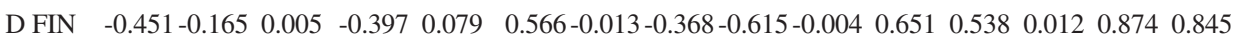

$\begin{array}{llllll}1 & 0.938 & 0.899-0.454 & 0.584 & 0.910 & 0.880\end{array}$ $\begin{array}{lllllllllllllll}0.091 & 0.557 & 0.985 & 0.143 & 0.781 & 0.028 & 0.963 & 0.178 & 0.015 & 0.988 & 0.009 & 0.039 & 0.966 & 0.000 & 0.000\end{array}$

$\begin{array}{lllllll}0 & 0.000 & 0.000 & 0.077 & 0.018 & 0.000 & 0.000\end{array}$

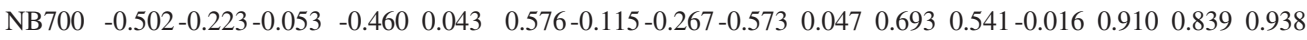

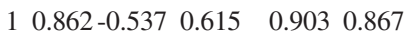
$\begin{array}{lllllllllllllllll}0.057 & 0.424 & 0.852 & 0.085 & 0.879 & 0.025 & 0.682 & 0.336 & 0.026 & 0.869 & 0.004 & 0.037 & 0.954 & 0.000 & 0.000 & 0.000\end{array}$

$\begin{array}{llllll}0 & 0.000 & 0.032 & 0.011 & 0.000 & 0.000\end{array}$

$\begin{array}{llllllllllllll}\mathrm{C} / \mathrm{W}^{2} & -0.280-0.107-0.008 & -0.298 & 0.002 & 0.267-0.019-0.172-0.401-0.006 & 0.458 & 0.344 & 0.083 & 0.882 & 0.801 & 0.899 & 0.862\end{array}$

$\begin{array}{llll}1-0.557 & 0.600 & 0.932 & 0.925\end{array}$

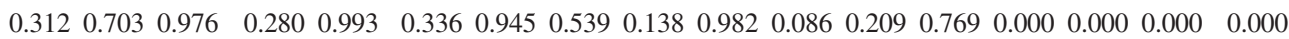

$\begin{array}{lllll}0 & 0.025 & 0.014 & 0.000 & 0.000\end{array}$

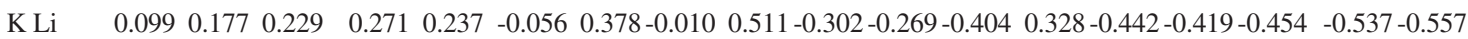

$1-0.824-0.489-0.548$ $\begin{array}{llllllllllllllllllllll}0.725 & 0.528 & 0.412 & 0.329 & 0.394 & 0.842 & 0.165 & 0.971 & 0.052 & 0.274 & 0.333 & 0.135 & 0.233 & 0.086 & 0.106 & 0.077 & 0.032 & 0.025 & 0 & 0.000 & 0.055 & 0.028\end{array}$

$\begin{array}{llllllllllllll}\text { CEL } & 0.004-0.070-0.127 & -0.215-0.123 & 0.219-0.100-0.227-0.614 & 0.178 & 0.354 & 0.490-0.166 & 0.515 & 0.574 & 0.584 & 0.615 & 0.600-0.824\end{array}$

$1 \quad 0.5630 .606$

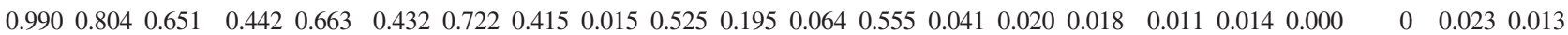

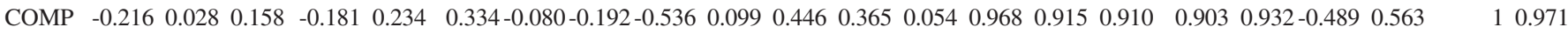
$\begin{array}{lllllllllllllllllllllll}0.440 & 0.923 & 0.575 & 0.518 & 0.401 & 0.224 & 0.777 & 0.493 & 0.039 & 0.726 & 0.095 & 0.181 & 0.847 & 0.000 & 0.000 & 0.000 & 0.000 & 0.000 & 0.055 & 0.023 & 0 & 0.000\end{array}$

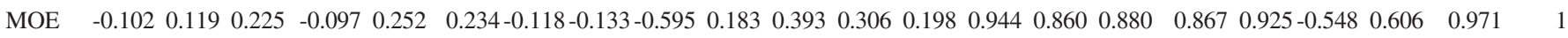

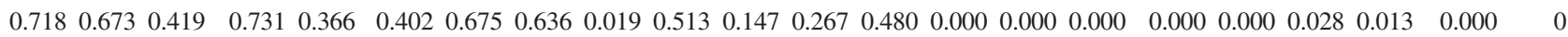

Fortunately, according to our results and various authors $[9,12,21]$ no significant trade-off would be required to improve growth and wood/fibre traits. Thus, the main problem faced by breeders is the strong genetic correlation between the fibre coarseness - affecting the TMP strength - and the wood stiffness, which will compel the tree breeders to trade off between the two targets, with probable weak selection gain. This is the same issue as for wood machinability and wood stiffness.

The alternative of considering wood quality "safeguards" to avoid selecting unsuitable genetic material for processing may be more reasonable. It could be thus suggested to select families on adaptation traits, growth and branch characteristics [2], then to define some thresholds for industrial acceptability: basic density and stiffness, within ring heterogeneity and maybe heartwood colour.

\section{CONCLUSION}

It is possible to use non destructive predictors for wood quality selection within Douglas fir provenances (Washington and Oregon) with a range of variability which is worth while being taken into consideration. For TMP process, large variation was observed for all properties, so there is potential to substantially increase pulp strength and brightness. The same conclusions could be given for chemical pulp processes, with the support of rapid non destructive techniques 
of estimation of chemical properties like infra-red spectroscopy, which now is operational for Douglas fir (Da Silva Perez, unpublished).

The main problem facing Douglas fir breeding is the antagonism between two targets: decreasing wood heterogeneity and enhancing wood stiffness, so that little gain should be expected for both. "Wood quality safeguards" within genetic material selected for adaptation traits could be an alternative to avoid the risk of reducing wood quality in Douglas fir, for structural uses as well as for pulping.

Before breeding for pulping traits, emphasis may be also given to the log segregation, by defining Douglas fir wood assortments better adapted for various pulp quality targets. For instance, using preferentially sawing chips and top logs for pulping, in order to decrease the prejudice due to high level of extractives content (affecting Kraft pulping yield, and increasing the COD of the bleaching effluents in the TMP process) or orientating Douglas fir sawing chips towards paper products requiring high tear index, but not for printing papers requiring smoothness like LWC. Moreover, improvement of the TMP process is still needed to easily use Douglas fir chips (chemical pre-treatment).

Aknowledgments: This research has been achieved with the support of the European Union (EUDIREC, FAIR CT 95-0909).

\section{REFERENCES}

[1] Abdelgadir A.Y., Krahmer R.L., Mc Kimmy M.D., Intraring variations in mature Douglas fir trees from provenance plantations, Wood Fiber Sci. 25 (1993) 170-181.

[2] Adams W.T., Bastien J.C., Genetics of second flushing in a French plantation of Douglas fir, Silvae Genet. 43 (1994) 345-352.

[3] Berruyer R., Étude des propriétés des fibres du bois de douglas, Rapport de stage INA PG/AFOCEL, 1996, 25 p.

[4] Chantre G., Sutter Barrot E., Gouma R., Bouvet A., De l'intérêt de l'utilisation du Pilodyn dans l'étude de la qualité du bois. Application à l'épicéa commun et l'épicéa de Sitka, Ann. Rech. For. AFOCEL (1992) 145-177.

[5] Chantre G., Bouvet A., Bongrand O., Robin E., Sens D., Modeling the kraft fibre morphology and the paper properties from forest data: the example of maritime pine thinning logs (Pinus pinaster sp.), TAPPI 2000 Pulping, Process \& Product Quality Conference, Boston, November 5-9, 2000.

[6] Fauchon T., Dahlqvist G., Mraz P., Cleuet J.C., Chantre G., Modelling relationships between wood and fiber properties and thermo-mechanical pulp properties through a new TMP pilot unit. Part I: Description of the method, Tappi Conference, Seattle, USA, November 2001.

[7] Foesser M., Chantre G., Rueff M., Petit-Conil M., Evaluation of thermo-mechanical ability of poplar and Douglas fir wood, by means of a micro-pilot plant method. Timber Management Toward Wood Quality and End-Product Value, 1997 CTIA/IUFRO International Wood Quality Workshop, Quebec, Canada, August 18-22, 1997, pp. 31-46.

[8] Ivkovich M., Koshy M., Optimisation of multiple trait selection in western hemlock (Tsuga heterophylla (Raf.) Sarg.) including pulp and paper properties, Ann. For. Sci. 59 (2002) 577-582.

[9] Keller R., Thoby M., Liaison entre l'état juvénile et l'état adulte pour quelques caractéristiques technologiques et auxométriques chez le Douglas, Ann. Sci. For. 34 (1977) 175-203.

[10] Mothe F., Aptitude au déroulage du bois de douglas. Conséquences de l'hétérogénéité du bois sur la qualité des placages, Thèse de docteur en sciences du bois, INPL, 1988.

[11] Movassaghi E., Influence des paramètres micro-densitométriques du bois sur les efforts de coupe et la qualité des placages de Douglas et de Chataignier obtenus par déroulage, Thèse de docteur ingénieur, INPL Nancy, 1985.

[12] Nepveu G., Variabilité génétique de la qualité du bois chez l'épicéa et le Douglas, Rev. For. Fr. 36 (1984) 303-312.

[13] Nepveu G., Tran Ngoc T., Relations entre les composantes densitométriques et l'état de surface des planches rabotées chez Pseudotsuga menziesii, Ann. Sci. For. 41 (1984) 171-194.

[14] Nepveu G., Blachon J.L., Largeur de cerne et aptitude à l'usage en structure de quelques conifères : Douglas, pin sylvestre, pin maritime, épicéa de Sitka, épicéa commun, sapin pectiné, Rev. For. Fr. 41 (1989) 497-506.

[15] Oto H., Suzuki E., Yushida T., Research on some aspects of TM, TAPPI/CPPA High yield pulping Seminar, Proceedings, 1978, p. 29.

[16] Petit-Conil M., Balme C., Cottin F., Guner N., Martinez J., Utilisation du Douglas dans la fabrication de pâtes à haut rendement. Partie III : blanchiment à l'hydrosulfite, effet de la variabilité du bois sur la qualité des pâtes TMP, Collaboration AFOCEL/CTP, no 3842, 1997, 16 p.

[17] Quick T., Siebers M., Hanes D., Thermo mechanical pulping of Douglas fir: mill and lab experiences at Smurfit Newsprint Corporation, International Mechanical Pulping Conference, Minneapolis, 1984, p. 259.

[18] Rozenberg P., Franc A., Chantre G., Baonza V., Indirect genetic selection of end-products wood properties: a method suitable for both tropical and temperate forest trees, South. Afr. For. J. 190 (2001) 99-104.

[19] Saint Clair J.B., Genetic variation in tree structure and its relation to size in Douglas fir. 1. Biomass, partitioning, foliage efficiency, stem form and wood density, Can. J. For. Res. 24 (1994) 1226-1235.

[20] Van Der Zee M.E., Helmink A.T.F., Velthuisen J.J., Improvement of brightness of Douglas fir TMP by addition of anti oxidizing agent and EDTA, 7th International Symposium on Wood and Pulping Chemistry, Beijing, 1993, p. 141.

[21] Vonnet G., Contribution à l'étude de la variabilité génétique de la densité et de l'hétérogénéité du bois de Douglas, DEA de biologie végétale, option Sciences Forestières, Station d'Amélioration des Arbres Forestiers CRF, Orléans, 1983. 
